\title{
RELEVANSI MISI KRISTUS BAGI SPIRITUALITAS KRISTEN
}

Made Nopen Supriadi, Minggus Dilla, Lewi Nataniel Bora

Sekolah Tinggi Teologi Arastamar Bengkulu

Sekolah Tinggi Teologi Injili Arastamar Setia Jakarta

madenopensupriadi@sttab.ac.id,minggusdilla@sttab.ac.id, lewi@sttsetia.ac.id

\begin{abstract}
Abstrac
Spirituality is an integral part of Christian life. Christian spirituality is built on the life andexample of Jesus Christ. The problem that occurs in Christian life today is that spirituality tends to be subjective and has no correlation with fellow human beings, there is even a spirituality that only exalts spiritual things and ignores disciplines that are important in this life and spirituality that actually causes ascetic action. which hurts yourself. Through the descriptive analysis method, the writer will study the problems of spirituality. The author examines that the life of Jesus' ministry in his mission has three important aspects, namely evangelism, teaching, and healing. Thus the author will provide answers to the above problems based on the life and mission of the ministry of Jesus Christ. This research has the novelty specifically to provide the concept of spirituality that is correlated with social, scientific, and medical realities.
\end{abstract}

Keywords: Relevance, Mission of Jesus, Spirituality.

\begin{abstract}
Abstrak
Spiritualitas merupakan bagian penting dalam kehidupan umat Kristen. Spiritualitas Kristen dibangun berdasarkan kehidupan dan teladan dari Yesus Kristus. Problematika yang terjadi dalam kehidupan umat Kristen saat ini adalah spiritualitas yang cenderung bersifat subyektif dan tidak memiliki korelasi dengan sesama manusia, bahkan ada spiritualitas yang hanya meninggikan hal-hal spiritual dan mengabaikan disiplin ilmu yang penting dalam kehidupan ini dan spiritualitas yang justru menyebabkan terjadinya tindakan asketis yang menyakitkan diri sendiri. Melalui metode analisis deskriptif penulis akan melakukan kajian terhadap problematika kehidupan spiritualitas. Penulis meneliti bahwa kehidupan pelayanan Yesus dalam misinya memiliki tiga aspek penting yaitu penginjilan, pengajaran dan penyembuhan. Dengan demikian penulis akan memberikan jawaban terhadap problematika di atas berdasarkan kehidupan misi pelayanan Yesus Kristus. Penelitian ini memiliki kebaharuan secara khusus memberikan konsep kehidupan spiritualitas yang berkorelasi dengan realitas sosial, ilmu pengetahuan dan medis.
\end{abstract}

Kata Kunci: Relevansi, Misi Yesus, Spiritualitas.

\section{PENDAHULUAN}

Manusia secara umum tidak bisa menghindari adanya relasi spiritualitas dalam kehidupannya. Sekalipun manusia memiliki konsep tidak percaya terhadap 
Tuhan atau hal-hal yang supranatural, namun tidak ada manusia yang tidak memiliki rasa takut, saat kondisi ketakutan manusia secara natur akan memerlukan sebuah pengharapan yang melampaui dirinya sendiri. Yohanes Calvin dalam membahas tentang doa dalam institutio menuliskan, bahwa manusia pada waktu menghadapi keadaan kristis akan kembali kepada naturnya, manusia akan berteriak kepada sesuatu yang melampaui dirinya yang dianggapnya bisa menolong, apakah itu Tuhan, atau yang lainnya. Dengan demikian konsep perasaan beragama (sensus divinitas) merupakan bagian yang mutlak dimiliki oleh semua manusia. ${ }^{1}$ Kehidupan spiritualitas adalah refleksi dari yang diimani. Perwujudan spiritualitas akan melahirkan religiusitas. Spiritualitas Kristen adalah sebuah kehidupan rohani yang mendasarkan pada kehidupan Yesus Kristus. ${ }^{2}$ Alkitab sebagai dasar dan sumber iman bagi keKristenan, memberikan banyak catatan penting tentang kehidupan Yesus. Salah satu hal penting tersebut adalah pelayanan misi yang dilakukan oleh Yesus Kristus.

Spiritualitas merupakan bagian dalam kehidupan seluruh manusia, relasi manusia terhadap Tuhannya diimplementasikan dalam berbagai ekspresi, sehingga ada manusia yang menunjukkan spiritualitasnya dengan cara menyiksa diri, bertapa dan menjalani banyak larangan, karena mempunyai perasaan bahwa tindakan tersebutlah mampu memberikan sebuah rasa dekat kepada Tuhan. ${ }^{3}$ Kemudian ada manusia yang melakukan tindakan dengan menghindari segala kemajuan zaman dengan mengasingkan diri dan melakukan tindakan yang tradisional semata, karena memiliki konsep konteks kehidupan demikianlah yang mampu memberikan rasa dekat kepada apa yang dipercaya. ${ }^{4}$ Selanjutnya ada juga fenomena refleksi spiritualitas dengan memutlakkan sebuah penderitaan bahkan sakit penyakit sebagai sebuah perwujudnyataan relasi kepada apa yang dipercaya. ${ }^{5}$ Dengan demikian secara umum ada banyak ekspresi dari sebuah spiritualitas yang diyakini sebagai kebenaran dalam membangun relasi kepada Tuhan baik secara individu dan komunal.

Penulis mengamati pada masa kini masih banyak orang percaya yang merefleksikan spiritualitasnya dalam konsep kehidupan non Kristen, ada kelompok Kristen tertentu yang menerapkan sebuah spiritualitas yang eksklusif atau menutup diri, sehingga dalam kehidupan spiritualitas penginjilan tidak terlaksana, apakah tepat berdasarkan kehidupan spiritualitas yang demikian?. ${ }^{6}$ Selanjutnya ada beberapa kelompok Kristen yang menerapkan pola kehidupan spiritualitas dengan mengisolasi diri dari dunia dan menolak terbuka pada perkembangan ilmu pengetahuan (science), ${ }^{7}$ namun dibagian lain ada juga kelompok Kristen yang terlalu terbuka serta menerima segala ilmu pengetahuan dalam kehidupan spiritualnya sehingga membentuk konsep

\footnotetext{
${ }^{1}$ Agustina Pasang, 'Spiritualitas Menurut Yohanes Calvin Dan Implikasinya Bagi Pendidikan Warga Gereja Di Era New Normal', PEADA': Jurnal Pendidikan Kristen, 1.2 (2020), 102-15.

${ }^{2}$ Manase Gulo, 'Membangun Spiritualitas Berdasarkan Surat 1 Timotius 4: 12', Manna Rafflesia, 1.1 (2014), 36-53 <https://doi.org/10.38091/man_raf.v1i1.44>.

${ }^{3}$ Labib Marzuki Shobir, 'Spiritualitas Dalam Perspektif Agama-Agama: Sebuah Pencarian Titik Temu', Indonesian Journal of Humanities and Social Sciences, 1.1 (2020), 118-30.

${ }^{4}$ Yasmin Kartikasari, 'Alam, Manusia, Dan Spiritualitas', Jurnal Sosioteknologi, 10.24 (2011), $1157-67$.

${ }^{5}$ Natanael Setiadi Kurniawan, 'Jika Aku Lemah, Maka Aku Kuat: Spiritualitas Eka Darmaputera Bergumul Dengan Sakit-Penyakit', Gema Teologi, 36.1 (2013).

6 Mariani Febriana, 'Puritan Dan Pemuridan: Mind, Heart And Life In The Making', SOLA GRATIA: Jurnal Teologi Biblika Dan Praktika, 5.1 (2017).

7 Darius Ade Putra, "“AKU, TUHAN DAN ALAM": Analisis Teologis-Spiritualitas Kristen Di Balik Lagu 'Berita Kepada Kawan'Karya Ebiet G. Ade', Tumou Tou, 2018, 60-71.
} 
spiritualitas yang didasarkan pada liberalisme. ${ }^{8}$ Maka di antara keduanya manakah yang perlu diterapkan?. Fenomena kehidupan spiritual Kristen pada masa kini juga diperhadapkan dengan kehidupan kekristenan yang terlalu menekankan penderitaan, sehingga pengorbanan yang menyebabkan sakit penyakit dinilai sebagai sebuah kehidupan spiritualitas yang utama, namun ada juga kelompok kristen yang membangun konsep spiritualitas dengan kesembuhan dan kemakmuran, sehingga menilai penderitaan sebagai sebuah kutukan dan keberdosaan, sedangkan kebahagiaan dan kesuksesan menjadi standar penilaian sebagai spiritualitas yang bertumbuh. ${ }^{9}$

Filsafat dan pola kehidupan dunia saat ini, memberikan banyak pengaruh kepada orang percaya. Terutama pada era postmodernism. ${ }^{10}$ Prinsip-prinsip hidup manusia mulai mengalami banyak pergeseran manusia mulai mencari sebuah pegangan yang dirasakan nyaman bagi hidupnya. Meskipun hal tersebut bukanlah hal yang bernilai ultimat. Keadaan demikian juga mempengaruhi kehidupan banyak orang Kristen, spiritualitas kehidupan zaman ini membawa banyak orang Kristen gagal mengimplementasikan hidup agamanya berdasarkan pada Alkitab dan pribadi Yesus Kristus. $^{11}$

Individualisme semakin mendorong manusia untuk hidup sesuai dengan apa yang menjadi keinginannya. Kondisi demikian bisa merapuhkan ikatan persatuan dan kebersamaan dalam kehidupan sosial. Banyak manusia mulai membangun spiritualitas yang justru menjauhkan diri dari kebersamaan, hal tersebut terlihat dari tawarantawaran praktek agama zaman baru yang menawarkan praktek spiritualitas yang memfokuskan kepada diri manusia. ${ }^{12}$ Sehingga banyak manusia cenderung berpikir bahwa membangun spiritualitas adalah cukup membangun diri sendiri dan banyak mengabaikan sesama manusia. Padahal refleksi iman percaya adalah dengan menjadi saksi. ${ }^{13}$

Yesus Kristus memberikan teladan, bahwa ketika ia menunjukkan spiritualitas kehidupan-Nya dalam pelayanan. Yesus melaksanakan tindakan misi dengan spiritualitas yang benar. Hal tersebut memperlihatkan bahwa misi Yesus dapat dijadikan teladan dalam membangun spiritualitas. Pada tulisan ini akan memaparkan mengenai pelayanan misi yang dilakukan oleh Yesus Kristus sesuai dengan apa yang dicatat di dalam Alkitab. Melalui pelayanan misi yang dilakukan oleh Yesus maka akan dirumuskan prinsip-prinsip spiritualitas bagi kehidupan Kristen. Oleh karena itu tulisan ini sangat penting, karena memaparkan pentingnya membangun spiritualitas yang Christocentric. ${ }^{14}$ Sehingga diharapkan melalui tulisan ini dapat memberikan kontribusi

${ }^{8}$ Marsono Marsono, 'Konsep Ketuhanan Dalam Filsafat Postmodernisme Perspektif Karen Amstrong', Sanjiwani: Jurnal Filsafat, 9.2 (2018), 157-64. Iman', 1991.

9 Cornelius Kuswanto, 'Teologi Kemakmuran--Menjatuhkan Iman, Teologi Salib--Menguatkan

${ }^{10}$ Kata post merupakan sebuah preposisi, yang memiliki 2 arti, yaitu: pertama, berkaitan dengan tempat, dimana kata post berarti di belakang. Kedua, berkaitan dengan waktu dan urutan, kata post berarti kemudian, sesudah atau berikutnya. (Lih. K. Prent, Kamus Latin-Indonesia (Yogyakarta: Kanisius, 1969), 658.)

11 Kees de Jong, 'Hidup Rukun Sebagai Orang Kristen Spiritualitas Dari Segi Theologia Religionum', Gema Teologi, 30.2 (2006).

${ }^{12}$ Wiersbe menjelaskan sebagai tugas besar untuk dilaksanakan, dan dimanapun orang percaya haruslah menjadi saksi (Lih. : Warren W. Wiersbe, The Bible Exposition Commentary; An Exposition of The New Testament Comprising the Entire “BE” Series (Illionis: Victor Books, 1989), 107.)

${ }^{13}$ David J. Bosch, Transformasi Misi Kristen (Jakarta: BPK Gunung Mulia, 2008), 22.

${ }^{14}$ Michael Bauman, 'Theological Spirituality: A Summons to Christocentrism', 2005. 
dalam membangun, membenahi dan mengembangkan kehidupan spiritualitas yang juga bermisi.

Merespon fenomena di atas penulis mengidentifikasi permasalah tersebut adalah problematika karena konsep misi yang bergeser dalam kehidupan banyak umat Kristen. Pelaksanaan misi kembali dipertanyakan dalam konteks kehidupan yang majemuk di Indonesia, apakah misi masih relevan dalam kehidupan umat Kristen?, atau adakah pengaruh tindakan misi bagi kehidupan spiritualitas Kristen?. Alkitab memberikan deskripsi penting bagaimana Yesus selama hidup di dunia melakukan tindakan misi, secara garis besar tindakan misi Yesus tersebut dilakukan dalam bentuk pemberitaan kabar baik atau penginjilan, memberikan pengajaran dan melakukan penyembuhan. Dengan demikian tulisan ini akan membahas tentang relevansi misi Kristus bagi spiritualitas Kristen.

\section{METODE}

Penelitian ini menerapkan metode analisis deskriptif. Penulis akan melakukan analisis fenomenologis serta memberikan jawaban terhadap fenomena melalui landasan teori yang penulis gunakan. ${ }^{15}$ Sugiyono menjelaskan tentang analisis deskriptif sebagai analisis data yang telah ada, data dijelaskan sesuai dengan sumber yang ada, namun tidak melakukan generalisir data. ${ }^{16}$ Dengan demikian pada penelitian ini menerapkan pola topikal artinya menetapkan point-point yang telah diakui sebagai landasan teori dan menjelaskan point tersebut sesuai dengan kelompok pembahasan. Metode penelitian ini juga bersifat teologis artinya ide atau pokok pemikiran tentang misi Kristus diadopsi dari pemikiran yang telah disepakati oleh para misiolog sebelumnya. ${ }^{17}$ Dengan demikian melalui metode analisis deskriptif teologis penulis memberikan penjelasan point-point pokok dari misi Kristus, penjelasan tersebut sampai pada relevansi pada masa kini.

\section{HASIL DAN PEMBAHASAN}

Penelitian ini memberikan kontribusi kepada umat Kristen dalam memahami kehidupan spiritualitas. Konsep yang diberikan dalam penelitian ini adalah membangun kehidupan spiritual didasarkan pada pelayanan misi Yesus Kristus dalam penginjilan, pengajaran dan penyembuhan. Penelitian ini juga memberikan wawasan kehidupan Kristen yang tetap menjaga spiritualitas namun tetap melakukan relasi kepada sesama manusia secara sosial dan terbuka pada perkembangan kemajuan kehidupan dalam ilmu pengetahuan. Melalui penelitian ini umat Kristen diharapkan dapat memahami sebuah keseimbangan kehidupan spiritualitas yaitu beriman, bersosialisasi dan berilmu. Melalui metode analisis deskriptif penelitian ini akan memaparkan banyak pemikiran secara teoritis tentang spiritualitas Kristen dan konsep pelayanan misi dari Yesus Kristus. Dengan demikian penelitian ini merupakan sebuah analisis untuk menjawab fenomena pergeseran kehidupan spiritualitas Kristen dengan tolak ukur pelayanan Yesus Kristus.

\footnotetext{
15 Sonny Eli Zaluchu, 'Strategi Penelitian Kualitatif Dan Kuantitatif Di Dalam Penelitian Agama', Evangelikal: Jurnal Teologi Injili Dan Pembinaan Warga Jemaat, 4.1 (2020), 28-38 <https://dx.doi.org/10.46445/ejti.v4i1.167>.

16 Sugiyono Sugiyono, Metode Penelitian Pendidikan, Pendekatan Kuantitatif, Kualitatif (Bandung: Alfabeta, 2009), p. 169.

${ }^{17}$ Stevri Indra Lumintang and Danik Astuti, Theologia Penelitian Dan Penelitian Theologis ScienceAscience Serta Metodologinya (Jakarta: Geneva Insani Indonesia, 2016), p. 10.
} 
Spiritualitas Kristen artinya kehidupan rohani dari umat Kristen yang didasarkan pada ajaran-ajaran Kristen. ${ }^{18}$ Salah satu ajaran dalam keKristenan adalah pelayanan misi oleh Yesus. Misi dalam iman Kristen tidak hanya diartikan sebagai pemberitaan Injil, tetapi misi berbicara juga mengenai keberadaan orang Kristen di lingkungannya. ${ }^{19}$ Pelayanan misi oleh Yesus bersifat holistik, di dalamnya ada Pekabaran Injil tentang Kerajaan Allah, pelayanan sosial, pendidikan, kesehatan, pemerintahan dan keagamaan. Istilah serupa menunjukkan kesamaan dan mengikuti.

Dengan demikian tulisan ini membahas tentang membangun spiritualitas berdasarkan dari teladan Yesus yang melakukan misi secara holistik dalam berbagai bidang kehidupan. Maka serupa di dalam misi Kristus menunjukkan kepada spiritualitas orang percaya yang melakukan tindakan misi seperti yang dilakukan oleh Yesus. Oleh karena itu tulisan ini akan menyajikan beberapa prinsip penting bagaimana Yesus melakukan misi dan bidang apa saja yang menjadi cakupannya.

Misi Kristus adalah misi Allah Tritunggal (Misi Trinitarian). Misi Allah Tritunggal berfokus pada pewartaan Kerajaan Allah, yang di dalamnya menghadirkan karya penebusan serta pemulihan. Yesus melakukan misi-Nya sesuai dengan kehendak Bapa-Nya dan misi yang Yesus lakukan juga dipimpin oleh Roh Kudus. Misi Allah Tritunggal dinyatakan langsung secara sempurna di dalam dan melalui Yesus Kristus. Misi yang dilakukan Yesus mencakup keseluruhan aspek kehidupan manusia. Misi itu dinyatakan baik menjangkau apsek spiritual, moral dan sosial. ${ }^{20}$ Hal tersebut dapat dilihat dalam tindakan Yesus yang melaksanakan penginjilan, pengajaran dan penyembuhan.

\section{Penginjilan}

Yesus dalam tindakan misinya banyak memberitakan tentang Injil atau Kabar Baik. Injil yang Yesus beritakan berpusat kepada Kerajaan Sorga. Yesus memberitakan pertobatan dan pengampunan serta memberitakan penggenapan Mesianik di dalam DiriNya. Sepanjang pelayanan Yesus kabar baik selalu dibagikan kepada para Murid dan pengikut-Nya. Kabar Baik yang Yesus bagikan adalah Berita tentang pengampunan dosa digenapi di dalam Diri-Nya. Namun konteks saat itu beberapa kelompok yang memiliki konsep berbeda tentang Mesias mengharapkan Yesus adalah seorang yang akan membebaskan dan membangun kembali Kerajaan Israel secara politis sama seperti pada zaman Daud. Yesus memperlihatkan bagaimana pemberitaan Injil sebagai bagian dari misi adalah hal penting. Spiritualitas dan penginjilan adalah bagian integral yang tidak terpisahkan. Yesus menunjukkan bahwa spiritualitas yang benar adalah

${ }^{18}$ Kata Spiritualitas berasal dari kata spiritus (Lat.) atau Spirit (Ingg.) yang artinya roh dan semangat. Kata ini menunjukkan kepada substansi non materil. Dalam konteks Alkitab spiritualitas berkaitan erat dengan hidup yang dipimpin oleh Roh. Dengan demikian Spirtualitas adalah keberadaan seseorang yang tahun bagaimana berelasi dengan Tuhan dan sesama berdasarkan dari Firman Tuhan (Alkitab). (Lih. : Sarah Andrianti, 'Pendidikan Kristen: Keseimbangan Antara Intelektualitas Dan Spiritualitas', Antusia: Jurnal Teologi dan Pelayanan', STT Intheos, 2.2 (2012), 14 <https://sttintheos.ac.id/e-journal /index.php /antusias /article/view /32 /31> [accessed 9 September 2020].)

19 Istilah misi berasal dari bahasa Latin Misio yang diangkat dari kata dasar mittere yang berkaitan dengan kata Misum yang berarti to send (mengirim atau mengutus). Dalam bahasa Yunani kata misi berasal dari kata apostello yang berarti mengirim atau mengutus dengan kuasa (Lih. : Yakub Tomatala, Teologi Misi (Jakarta: Leadership Foundation, 2003), 16.)

20 Manase Gulo, 'Sketsa Glocal Theology', Manna Rafflesia, 6.2 (2020), 135-57 <https://doi.org/10.38091/man_raf.v6i2.113>. 
melaksanakan misi penginjilan untuk menolong spiritualitas orang lain. ${ }^{21}$ Dengan demikian spiritualitas dalam misi penginjilan yang Yesus lakukan, menunjukkan sebuah gaya hidup yang terbuka bagi kehidupan sosial. Pemberitaan Injil membawa Yesus hadir di tengah-tengah komunitas Sosial. Kehadiran di komunitas sosial hanya untuk memberikan pemulihan spiritual. ${ }^{22}$

Pemberitaan Injil yang dilakukan Yesus juga terkadang disertai dengan pengusiran setan. Pengusiran tersebut sebagai tanda hadirnya Kerajaan Allah dan pulihnya spiritualitas. Penginjilan yang dilakukan oleh Yesus bertujuan untuk memberikan pemulihan secara rohani kepada banyak orang saat itu. Dengan demikian misi Yesus yang diimplementaskan di dalam penginjilan bertujuan untuk membawa manusia yang miskin dan lapar serta haus secara rohani dipulihkan. ${ }^{23}$ Pemulihan rohani inilah yang justru ditolak oleh beberapa kelompok yang hadir dalam pelayanan Yesus. Puncak pemulihan spiritual ini terealisasi pada waktu Yesus mati di kayu salib dan bangkit dari kematian serta naik ke Sorga.

\section{Pengajaran}

Yesus dalam pelaksanaan misi-Nya banyak memberikan pengajaran. Pengajaran tersebut tidak hanya mencakup mengenai hukum Taurat, tetapi ajaran Yesus secara prinsip mampu menjangkau semua apsek kehidupan manusia. Yesus memberikan prinsip dalam kehidupan sosial agar manusia saling mengasihi. Yesus memberikan prinsip secara politik agar manusia memberikan apa yang menjadi kewajiban bagi kaisar dan apa yang menjadi kewajiban bagi Allah. Yesus memberikan pengajaran tentang prinsip sosial dan moral dengan mencari dan menyelamatkan orang yang berdosa. Yesus mengajarkan tentang prinsip bekerja untuk giat melayani selama masih siang. ${ }^{24}$ Dengan demikian misi Yesus juga memberikan pengajaran yang mencerdaskan manusia. Yesus sudah memulai peran-Nya sebagai pendidik dalam tindakan misi-Nya. Pelayanan Yesus ini juga memiliki hasil akhir yaitu terjadinya pemulihan kehidupan manusia dalam segi pendidikan. Manusia dibukakan akan hikmat, baik itu hikmat tentang firman Tuhan dan hikmat tentang prinsip-prinsip kehidupan. ${ }^{25}$ Pengajaran yang Yesus lakukan memberikan dampak untuk Murid dan pengikut-Nya terbuka akan

21 Roedy Silitonga, 'Implikasi Hubungan Kristus Dan Budaya Dalam Berbagai Konteks Penginjilan Yang Dihadapi Murid Kristus', 2020, VIII.

22 Talan menuliskan: "Sama halnya dengan pertobatan Lewi pemungut cukai, setelah Yesus menyembuhkan banyak orang yang sakit lumpuh, Ia keluar dan menjumpai Lewi duduk di rumah cukai sedang melakukan tugasnya. Yesus berkata kepadanya ikutlah Aku. Dan Lewi pun meninggalkan segala sesuatu lalu mengikuti Dia. Dengan demikian dapat dipahami bahwa pelayanan Yohanes dan Yesus secara ekplisit menunjukan bahwa misi yang diperkenalkan dalam Injil Lukas adalah misi yang bersifat marturia. Yaitu bersaksi tentang kabar sukacita bahwa Allah mengasihi dunia ini dan telah mengaruniakan Anak-Nya untuk menebus manusia". (Lih. : Yesri Talan, 'Mengkaji Hakekat Misi Inklusif Yesus Berdasarkan Injil Lukas Dan Aplikasinya Bagi Misi Masa Kini', Manna Rafflesia,6.2(2020), 200-219 <https://doi.org/10.38091/man_raf.v6i2.116>.)

${ }^{23}$ Lewi Nataniel Bora, 'Keserupaan Dengan Yesus Dalam Penderitaan, Kesengsaraan Dan Kematian-Nya', Manna Rafflesia, 7.1 (2020), 65-89 <https://doi.org/10.38091/man_raf.v7i1.127>.

24 Waharman Waharman, 'Peran Orang Tua Dalam Pertumbuhan Spiritualitas Anak: Sebuah Studi Eksegetis Efesus 6:1-4', Manna Rafflesia, $4.2 \quad$ (2018), 116-29 <https://doi.org/10.38091/man_raf.v4i2.92>.

25 Markes menuliskan: "Demikian halnya Pendidikan Agama Kristen sebagai wadah pembelajaran dan pembinaan karakter Kristen diharapkan dapat mengembangkan karakter umat Kristen agar dapat bertumbuh menjadi pribadi yang berkarakter Kristus. (Lih. : Karlito D Markes, 'Living Values Education Dan Implikasinya Bagi Pendidikan Agama Kristen', Manna Rafflesia, 6.2 (2020), 220-40 $<$ https://doi.org/10.38091/man_raf.v6i2.120>. 
makna Hukum Taurat, meskipun ada banyak yang belum bisa menerima ajaran yang keras dari Yesus. Puncak realisasi pengajaran ini diteruskan oleh karya Roh Kudus yang menuntun orang percaya ke dalam kebenaran.

\section{Penyembuhan}

Misi Yesus juga menjangkau dalam tindakan penyembuhan. Banyak mujizat yang dilakukan oleh Yesus menunjukkan penyembuhan manusia dari penyakit. Yesus selain memberitakan Injil dan mengajar, Ia juga memperhatikan kondisi kesehatan orang-orang yang ada disekitar-Nya. Alkitab banyak memberikan catatan mengenai tindakan Yesus yang memberikan kesembuhan. Hal tersebut menunjukkan spiritualitas yang Yesus lakukan dalam misi memberikan kontribusi dalam aspek kesehatan manusia. Yesus banyak melakukan mujizat untuk meyembuhkan berbagai macam penyakit, bahkan penyakit yang dikategorikan sebagai penyakit kutukan dari Allah yaitu kusta dapat disembuhkan oleh Yesus. ${ }^{26}$ Tindakan misi Yesus dalam memperhatikan kesehatan juga memproklamirkan tentang diri-Nya sebagai Mesias.

Penyembuhan yang Yesus lakukan bertujuan untuk memberikan pemulihan secara fisik kepada manusia. Yesus melakukan hal tersebut bukan hanya sekedar show of power tetapi untuk menunjukkan integritas perkataan-Nya. Tindakan misi Yesus dalam memberikan pemulihan kesehatan bukan semata-mata untuk manusia yang dipulihkan itu sendiri, tetapi sebagai bagian dari proklamasi keIlahian-Nya kepada manusia. Namun banyak orang yang tidak menyadari tujuan ini, sehingga Yesus hanya dipandang sebagai penyembuh penyakit secara fisik. Namun ada juga orang yang disembuhkan Yesus secara fisik juga mengalami pemulihan secara rohani dan memutuskan untuk mengikut Yesus setelah dipulihkan. ${ }^{27}$ Puncak realisasi misi ini adalah pada waktu kedatangan Tuhan Yesus yang kedua kali dan orang percaya mengenakan tubuh kebangkitan.

Dari kajian tindakan misi Yesus maka dapat dirumuskan beberapa prinsip teologis untuk kehidupan spiritualitas. Oleh karena itu ada tiga prinsip yang akan diimplementasikan dalam kehidupan spiritualitas Kristen berdasarkan tindakan misi Kristus, yaitu: hidup memberitakan Injil, bersedia mempelajari disiplin ilmu dan menjaga kesehatan.

\section{Hidup Memberitakan Injil}

Para pengikut Kristus sudah sewajarnya meneladani kehidupan Yesus Kristus. Secara khusus dalam kehidupan misi yang dilakukan Yesus. Misi holistik yang dikerjakan oleh Yesus salah satunya penginjilan. Yesus memberitakan Kabar Baik kepada semua orang yang bersama dengan dia. Demikian juga hendaknya spiritualitas Kristen meneladani Yesus dalam memberitakan Kabar Baik. Pemberitaan Kabar Baik melibatkan adanya interaksi sosial dalam kehidupan orang percaya.

Pada masa kini orang percaya ditantang untuk memberitakan tentang berita keselamatan yang telah dikerjakan oleh Yesus. Dalam perkembangan kehidupan

${ }^{26}$ Supriadi menuliskan "Mujizat penyembuhan diberikan Allah sebagai upaya menopang pelayanan penginjilan para Murid kepada orang tidak percaya sehingga Injil semakin diteguhkan. Namun tanda-tanda tersebut tidak akan serta merta terlihat lagi dalam perkembangan gereja selanjutnya oleh karena Allah telah membukakan hikmat bagi manusia dan orang percaya." (Lih. : Made Nopen Supriadi, 'Penyembuhan Penyakit: Sebuah Studi Eksegetis Berdasarkan Markus 16:17-18', Manna Rafflesia, 4.2 (2018), 148-54 <https://doi.org/10.38091/man_raf.v4i2.94>.)

${ }^{27}$ Minggus Dilla, 'Pandangan Alkitab Tentang Okultisme', Manna Rafflesia, 2.1 (2015), 23-37 $<$ https://doi.org/10.38091/man_raf.v2i1.54〉. 
manusia yang semakin pesat dalam informasi dan teknologi, memberikan peluang kepada banyak orang percaya untuk bisa menceritakan Yesus melalui sarana media sosial. Spiritualitas yang meneladani Yesus justru membawa orang percaya tidak melihat dirinya sendiri tetapi berani untuk membiarkan orang lain melihat dirinya. Sehingga kehidupan dan perkataan orang percaya ditantang integritasnya.

Spritualitas dalam misi Kristus memberikan teladan untuk menyatakan bahwa Kabar Baik adalah pusat penting dalam perkataan. Meskipun di dalam Alkitab telah tertulis dengan jelas mandat Misi yang diberikan kepada orang percaya, namun yang mudah untuk dingat adalah melihat dan mengikuti teladan yang telah dilakukan oleh Yesus. Para murid tidak hanya dimotivasi oleh tulisan-tulisan atau kata-kata dari Yesus tetapi mereka melihat langsung teladan yang Yesus telah lakukan dalam penginjilan, sehingga teladan tersebut berbicara dan memotivasi lebih kuat di dalam kehidupan spiritualitas para Murid. Meksipun demikian peran dari Roh Kudus tidak bisa diabaikan, karena setelah pencurahan Roh Kudus spirtualitas para Murid menunjukkan keberanian yang total dalam memberitakan Injil.

\section{Bersedia Mempelajari Disiplin Ilmu}

Kehidupan spiritualitas yang mengikuti tindakan Yesus dalam bermisi memperlihatkan bahwa orang percaya memiliki tanggung jawab dalam mempelajari berbagai disiplin ilmu. Yesus banyak memberikan pengajaran kepada para Murid dan pengikut-Nya. Hal tersebut juga menjadi sebuah teladan spiritualitas bahwa kehidupan spiritualitas Kristen bukan hanya berbicara tentang membangun kehidupan secara pribadi, tetapi juga membangun kehidupan dalam konteks kebersamaan. Yesus memberikan pengajaran yang membuka pemikiran orang percaya, demikian juga orang percaya hendaknya memiliki tanggung jawab secara pribadi belajar banyak hal dalam kehidupannya dan memberikan pembelajaran yang berharga serta bernilai kepada sesama manusia.

Roh Kudus memiliki peran penting dalam kehidupan pembelajaran. Karena Roh Kudus yang memimpin manusia ke dalam kebenaran yang sejati. Kebenaran tersebut mendorong manusia untuk mau belajar bahkan banyak disiplin ilmu dapat digunakan sebagai sarana untuk dapat menjelaskan kebenaran. Yesus dalam pengajaran-Nya banyak menggunakan perumpaan yang diambil dari beragam konteks kehidupan manusia, baik itu petani, nelayan dan lain-lain. Analisis tersebut mengarahkan bahwa orang percaya pada masa kini perlu memiliki semangat belajar, karena ilmu yang didapat pasti dapat digunakan sebagai salah satu sarana untuk menjelaskan tentang kebenaran. Spiritualitas Kristen hendaknya tertuang dalam semangat membangun pendidikan yang berdasarkan pada Yesus Kristus. Sehingga hendaknya pendirian sekolah-sekolah Kristen didasarkan pada spiritualitas yang sejati yaitu meneladani Yesus Kristus. Yesus tidak meminta bayaran ketika dia memberikan pengajaran, Yesus tidak menuntut jabatan ketika Dia memberikan pengajaran dan Yesus tidak menuntut kehormatan ketika dia mengajar. Namun Yesus mengajar karena itulah spiritualitasNya. Dengan demikian spiritualitas yang sehat adalah dasar yang benar untuk memberikan pengajaran.

\section{Menjaga Kesehatan}

Misi Yesus direalisasikan dalam memberikan penyembuhan kepada banyak orang yang dilayani. Yesus memperhatikan aspek kesehatan, demikian juga orang percaya saat ini bentuk kehidupan spiritualitas yang sehat juga terfeleksi di dalam 
menjaga kesehatan hidup dan memberikan dampak yang sehat bagi sesama. Kesehatan adalah prinsip hidup yang penting, namun orang percaya bisa mendasarkannya pada teladan kehidupan Yesus yang juga memperhatikan kesehatan banyak orang yang mengikut-Nya.

Secara praktis orang percaya tetap harus menjaga kesehatan diri dan lingkungan. Meskipun tidak ada manusia yang akan terluput dari sakit penyakit, namun kesadaran bahwa manusia tidak terluput dari sakit penyakit tidaklah harus membuat orang percaya apatis dalam menjaga kesehatan. Yesus juga bisa merasakan sakit dan mengalami kematian tetapi selama hidup pelayanan-Nya Ia tetap memperhatikan kesehatan banyak orang. Demikian juga orang percaya yang diberikan hikmat dalam ilmu medis hendaknya memberikan pertolongan kesehatan karena didasarkan pada spirirtualitas yang meneladani Yesus Kristus.

Secara teologis benar bahwa pada kedatangan Tuhan Yesus yang kedua kali akan terjadi pemulihan atas segala ciptaan. Manusia akan mengenakan tubuh kebangkitan yang tidak akan sakit. Tetapi jangan karena pemikiran yang futuristik membuat kita membangun spiritualitas yang apatis terhadap kesehatan masa kini dan hanya berharap pada kesehatan di masa yang akan datang. Dengan demikian kehidupan spiritualitas yang sehat mendorong orang percaya bertanggung jawab juga terhadap kesehatan-Nya. Menjaga kesehatan dengan dasar spiritualitas yang meneladani Kristus adalah sebuah dasar yang sangat penting dalam kehidupan manusia. Karena tindakan yang dilakukan bukan hanya sekedar tulisan tetapi mengikuti teladan.

\section{KESIMPULAN}

Kehidupan manusia tidak terlepas dari kehidupan spiritual. Hal demikian juga terjadi dalam kehidupan orang yang percaya kepada Yesus Kristus. Spiritualitas Kristen adalah spiritualitas yang didasarkan pada teladan hidup Yesus Kristus. Teladan yang diberikan oleh Yesus salah satunya adalah tentang tindakan misi. Yesus dalam pelayanan misinya menunjukkan pelayanan dalam pekabaran Injil, pengajaran dan pemulihan. Teladan yang dilakukan oleh Yesus menunjukkan spiritualitas-Nya. Orang percaya ketika membangun spiritualitas maka perlu meneladani Yesus Kristus, sehingga dari tindakan misi Yesus maka spiritualitas orang percaya juga direfleksikan dengan melakukan pemberitaan Injil, mengembangkan pendidikan dan kesehatan. Dengan demikian spiritualitas Kristen bukan hanya dilaksanakan dalam dimensi rohani, tetapi juga dalam dimensi praktis. Spiritualitas Kristen yang mengikuti tindakan dan misi Kristus akan memperlihatkan kehidupan yang dinamis secara sosial. Orang percaya akan memiliki beban dan rasa untuk hadir bersama memulihkan kehidupan spiritual, moral dan sosial sesamanya.

\section{DAFTAR PUSTAKA}

Andrianti, Sarah, 'Pendidikan Kristen: Keseimbangan Antara Intelektualitas Dan Spiritualitas', Antusia: Jurnal Teologi dan Pelayanan', STT Intheos, 2.2 (2012), $14<$ https://sttintheos.ac.id/e-journal /index.php /antusias /article /view /32 /31> [accessed 9 September 2020]

Bauman, Michael, 'Theological Spirituality: A Summons to Christocentrism', 2005 
Bora, Lewi Nataniel, 'Keserupaan Dengan Yesus Dalam Penderitaan, Kesengsaraan Dan Kematian-Nya', Manna Rafflesia, 7.1 (2020), 65-89

<https://doi.org/10.38091/man_raf.v7i1.127>

Bosch, David J., Transformasi Misi Kristen (Jakarta: BPK Gunung Mulia, 2008)

Dilla, Minggus, 'Pandangan Alkitab Tentang Okultisme', Manna Rafflesia, 2.1 (2015), 23-37<https://doi.org/10.38091/man_raf.v2i1.54>

Febriana, Mariani, 'Puritan Dan Pemuridan: Mind, Heart And Life In The Making', SOLA GRATIA: Jurnal Teologi Biblika Dan Praktika, 5.1 (2017)

Gulo, Manase, 'Membangun Spiritualitas Berdasarkan Surat 1 Timotius 4: 12', Manna Rafflesia, 1.1 (2014), 36-53 <https://doi.org/10.38091/man_raf.v1i1.44>

—_, 'SKETSA GLOCAL THEOLOGY', Manna Rafflesia, 6.2 (2020), 135-57 <https://doi.org/10.38091/man_raf.v6i2.113>

de Jong, Kees, 'Hidup Rukun Sebagai Orang Kristen Spiritualitas Dari Segi Theologia Religionum', Gema Teologi, 30.2 (2006)

Kartikasari, Yasmin, 'Alam, Manusia, Dan Spiritualitas', Jurnal Sosioteknologi, 10.24 (2011), 1157-67

Kurniawan, Natanael Setiadi, 'Jika Aku Lemah, Maka Aku Kuat: Spiritualitas Eka Darmaputera Bergumul Dengan Sakit-Penyakit', Gema Teologi, 36.1 (2013)

Kuswanto, Cornelius, 'Teologi Kemakmuran--Menjatuhkan Iman, Teologi Salib-Menguatkan Iman’, 1991

Lumintang, Stevri Indra, and Danik Astuti, Theologia Penelitian Dan Penelitian Theologis Science-Ascience Serta Metodologinya (Jakarta: Geneva Insani Indonesia, 2016)

Markes, Karlito D, 'Living Values Education Dan Implikasinya Bagi Pendidikan Agama Kristen', Manna Rafflesia, 6.2 (2020), 220-40 <https://doi.org/10.38091/man_raf.v6i2.120>

Marsono, Marsono, 'Konsep Ketuhanan Dalam Filsafat Postmodernisme Perspektif Karen Amstrong', Sanjiwani: Jurnal Filsafat, 9.2 (2018), 157-64

Pasang, Agustina, 'Spiritualitas Menurut Yohanes Calvin Dan Implikasinya Bagi Pendidikan Warga Gereja Di Era New Normal', PEADA': Jurnal Pendidikan Kristen, 1.2 (2020), 102-15

Prent, K., Kamus Latin-Indonesia (Yogyakarta: Kanisius, 1969)

Putra, Darius Ade, “"AKU, TUHAN DAN ALAM": Analisis Teologis-Spiritualitas Kristen Di Balik Lagu 'Berita Kepada Kawan'Karya Ebiet G. Ade', Tumou Tou, 2018, 60-71 
Shobir, Labib Marzuki, 'Spiritualitas Dalam Perspektif Agama-Agama: Sebuah Pencarian Titik Temu', Indonesian Journal of Humanities and Social Sciences, 1.1 (2020), 118-30

Silitonga, Roedy, 'Implikasi Hubungan Kristus Dan Budaya Dalam Berbagai Konteks Penginjilan Yang Dihadapi Murid Kristus', 2020, VIII

Sugiyono, Sugiyono, Metode Penelitian Pendidikan, Pendekatan Kuantitatif, Kualitatif (Bandung: Alfabeta, 2009)

Supriadi, Made Nopen, 'Penyembuhan Penyakit: Sebuah Studi Eksegetis Berdasarkan Markus 16:17-18', Manna Rafflesia, 4.2 (2018), 148-54 <https://doi.org/10.38091/man_raf.v4i2.94>

Talan, Yesri, 'Mengkaji Hakekat Misi Inklusif Yesus Berdasarkan Injil Lukas Dan Aplikasinya Bagi Misi Masa Kini', Manna Rafflesia, 6.2 (2020), 200-219 <https://doi.org/10.38091/man_raf.v6i2.116>

Tomatala, Yakub, Teologi Misi (Jakarta: Leadership Foundation, 2003)

Waharman, Waharman, 'Peran Orang Tua Dalam Pertumbuhan Spiritualitas Anak: Sebuah Studi Eksegetis Efesus 6:1-4', Manna Rafflesia, 4.2 (2018), 116-29 <https://doi.org/10.38091/man_raf.v4i2.92>

Wiersbe, Warren W., The Bible Exposition Commentary; An Exposition of The New Testament Comprising the Entire “BE” Series (Illionis: Victor Books, 1989)

Zaluchu, Sonny Eli, 'Strategi Penelitian Kualitatif Dan Kuantitatif Di Dalam Penelitian Agama', Evangelikal: Jurnal Teologi Injili Dan Pembinaan Warga Jemaat, 4.1 (2020), 28-38 <https://dx.doi.org/10.46445/ejti.v4i1.167> 